\title{
Institutional Investment in Central and Eastern Europe: Investment Criteria of Western Portfolio Managers
}

\author{
F. Jens Köke \\ ZEW Discussion Paper No. 99-37
}

October 1999

\begin{abstract}
This study provides detailed evidence on the recent transition state of Central and Eastern European (CEE) countries. It draws on data from a survey conducted among portfolio managers of Western investment funds thereby making use of the knowledge of experts in CEE markets. The approach of the study is two-fold: First, criteria for portfolio investment and current barriers to higher investment in CEE countries are identified. Second, the CEE portfolio structure is explained making use of detailed grading data from the survey. The results suggest that a reduction in general and macroeconomic risk tends to increase investment and that the potential of high returns and low risk from the setting of financial markets contributes to significantly higher investment in some countries.
\end{abstract}

Key Words: Central and Eastern Europe; institutional investors; portfolio investment

JEL Classification: G11, G23, O10

Helpful comments from Herbert Buscher, Francois Laisney, Michael Schröder and Max Steiger (all ZEW) as well as Angelika Eymann and Olaf Korn (University of Mannheim) are gratefully acknowledged. The author also thanks participants of the conference on "Institutions in Transition" in Maribor/Slovenia, and in particular Mojmir Mrak (University of Ljubljana) for valuable suggestions. Excellent research assistance was provided by Heiko Truppel and Laura Manthey.

Address for correspondence:

Jens Köke

Phone: 0049-621-1235-190

Center for European Economic Research

Fax: 0049-621-1235-223

P.O. Box 103443

E-mail: koeke@zew.de

68034 Mannheim, Germany. 


\section{Non-Technical Summary}

Transition of the former communist countries of Central and Eastern Europe (CEE) to functioning market economies creates new investment opportunities. A decade ago capital markets were almost absent in all CEE countries but they are developing rapidly. At the end of the 1990s institutional investors from Western countries are present in the equity and bond markets of the largest CEE economies. However, deficits in the economic and institutional setting still restrict foreign investment in CEE countries.

This study examines the determinants of portfolio investment conducted by Western institutional investors in the Czech Republic, Estonia, Hungary, Poland and Slovenia as the five CEE candidates to the European Union. In addition, Russia is included as the largest country in Eastern Europe. The study focuses on the pull-factors of portfolio investment, i.e. analyzes the attractiveness of CEE capital markets from the perspective of Western investors.

The analysis draws on data from a recent survey conducted among portfolio managers of Western investment funds, an increasingly important type of institutional investor. The approach of this study is two-fold: First, criteria for portfolio investment and current barriers to higher investment in CEE countries are identified. Second, the CEE portfolio structure of Western investment funds is explained making use of detailed grading data from the survey.

The results suggest that fund managers check a whole catalogue of criteria. Most important are stability of the financial and legal system, managerial competency and liquidity of the stock market. But liquidity as a prerequisite for instantaneous exit from any investment is regarded as low in all CEE countries. Also managerial qualification - an important element of efficient corporate governance - is judged as low in most CEE countries.

An econometric analysis shows that a low level of perceived general and macroeconomic risk, a sound potential of return and low risk from the setting of financial markets tend to influence portfolio investment in all CEE countries positively. But there is some heterogeneity between the CEE countries: stability of the legal system drives investment in Hungary, whereas investment in the Czech Republic in Russia is barred by low managerial competency. In Slovenia, primarily low liquidity of the stock market limits portfolio investment . 


\section{Introduction}

World-wide, the share of assets which is managed by investment funds, pension funds and insurance companies - the so-called institutional investors - is increasing rapidly (OECD, 1999b). Their combined equity and bond holdings rose from 36 percent of GDP (1981) to 102 percent of GDP (1995) in the OECD area. Recently, the countries of Central and Eastern Europe (CEE) are also becoming a target of institutional investors, in particular Western investment funds.

The intent of this study is two-fold. First, we want to know which factors determine portfolio investment in CEE countries, and second, how the current CEE portfolio structure of Western institutional investors can be explained. These are important questions because capital is still scarce in CEE countries ${ }^{1}$ and since equity capital seems to play a larger role in CEE firms compared to Western firms (World Bank, 1997: 157). Making use of a recent survey among fund managers of Western investment funds we show which criteria fund managers use when they consider to invest in CEE equity markets. We also explore what kind of barriers to higher portfolio investment in CEE countries currently exist in their view and, in turn, which factors determine their investment. Applying an econometric analysis we attempt to explain the CEE portfolio structure of Western fund managers. This analysis also serves as a test on the robustness of our descriptive results.

Throughout this study portfolio investment is defined as capital which is invested by institutional foreign investors into CEE equity markets. ${ }^{2}$ Hence we do not analyze foreign investment in other securities such as ADR and GDR programs. ${ }^{3}$ The reason is that we want to focus on the pull-factors which attract foreign investment into the domestic CEE equity mar-

\footnotetext{
${ }^{1}$ See for example the OECD country reports on the Czech Republic (OECD 1998a), on Hungary (1997a), on Poland (1999a), on Russia (1997b) and on Slovenia (1997c).

${ }^{2}$ In section 3 we show that foreign investment in the bond markets of the CEE countries is highly correlated with investment in the equity markets. Therefore, we assume that the criteria for both forms of investment are similar.

${ }^{3}$ American Depository Receipts (ADR) and Global Depositary Receipts (GDR) are dollar-denominated certificates which represent shares of non-US companies but are traded, cleared and settled in the same way as US securities. The receipts were created in the late 1920s to facilitate US investor purchases of non-US securities and to allow non-US stock to be traded in the US. By May 1999, over 3.8 billion US\$ were invested in ADR and GDR programs of CEE enterprises (Budapest Business Journal 1999: 14). GDR programs dominate because GDRs give companies better access to European and other non-US investors than ADRs.
} 
kets. ${ }^{4}$ Since we are particularly interested in the functioning of domestic equity markets we also neglect foreign direct investment. ${ }^{5}$

For this study we make use of a unique source of data. From April to June 1999 the Center for European Economic Research (ZEW) conducted a survey among Western portfolio managers. Since they are active participants in CEE equity and bond markets we are able to draw on upto-date information about the current state and problems of the CEE transition process.

This study is organized as follows. Section 2 describes the set-up of the survey and the data we obtained. Section 3 gives a detailed description of the results from the survey. Whereas section 3 is primarily descriptive, section 4 provides empirical results on the determinants of portfolio investment in CEE countries from regression analysis. Section 5 concludes with some remarks on the policy implications for institutional change in CEE countries.

\section{Data}

The data used in this study were obtained through a survey which the Center for European Economic Research (ZEW) conducted from April to June 1999. Survey participants were Western portfolio managers who are responsible for investment in Central and Eastern Europe (CEE). Hence, we asked active market participants who are experts in CEE equity and bond markets. Intent of the survey was to find out what criteria fund managers use for their investment in CEE countries and what barriers to investment currently exist from their point of view.

The questionnaire was sent to 119 fund managers from 80 different funds which specialized in CEE countries. ${ }^{6}$ To increase the response rate all recipients of the questionnaire were contacted by phone in advance. In total, 21 questionnaires were sent back from 19 different funds. ${ }^{7}$ This is equal to a response rate of about 24 percent. At the end of the year 1998 these

\footnotetext{
${ }^{4}$ Hence we neglect the push-factors, e.g. liquidity of the funds, degree of competition in the fund industry etc) which can drive foreign portfolio investment.

${ }^{5}$ According to EU law foreign investment is labeled as direct investment when the investor buy more than 10 percent of the shares of the investment target. Share stakes below 10 percent are labeled portfolio investment.

${ }^{6}$ The full questionnaire can be found in the Appendix.

${ }^{7}$ Each recipient was additionally contacted up to three times by phone when he/she had not yet sent back the survey. However, the response rate of 23.75 percent (defined as responding funds as a percentage of all CEE funds) could not be increased further. Mostly the fund managers indicated severe time constraints.
} 
funds managed about 2,300 million Euro invested in stocks and bonds in the CEE countries. ${ }^{8}$ World-wide the total of their investment amounted to 1,100 billion Euro.

Through the survey we obtained data on the absolute size of each fund's investment position in six CEE countries: the Czech Republic, Hungary, Poland, Estonia, Slovenia as the five EU candidates and Russia as the largest country in Eastern Europe. Survey participants were given 23 criteria for investment: they were asked to rank these criteria by relevance for their personal investment decisions. Then they graded each of the six countries on these criteria. ${ }^{9}$ There are three distinct groups of criteria: macroeconomic environment and general political situation, microeconomic factors (like degree of competition and skill level of management), and the institutional framework of the financial markets (like minority shareholder protection or disclosure requirements, but also stock market liquidity).

\section{Descriptive Results}

Focussing on the five EU candidates and Russia the structure of Western funds' portfolios at the end of the year 1998 looked as follows: ${ }^{10}$

Table 1: Portfolio Structure of Western Investment Funds (end of 1998)

\begin{tabular}{lrrrrrrr}
\hline & $\begin{array}{r}\text { Czech Re- } \\
\text { public }\end{array}$ & Hungary & Poland & Estonia & Slovenia & Russia & Total \\
\hline Shares & 16.1 & 36.6 & 34.4 & 1.4 & 0.7 & 10.8 & 100.0 \\
Bonds & 14.9 & 40.7 & 27.8 & 0.9 & 0.6 & 15.1 & 100.0 \\
\hline
\end{tabular}

As can be seen from Table 1, Hungary attracted the largest amount of portfolio investment among the CEE countries, Poland the second largest. The much lower fraction of Czech shares and bonds in the Western portfolios contrasts with the total amount of foreign assets in 1997 which was - by that time - higher than in Hungary or Poland (IMF, 1999). However, the reduced importance of Czech assets at the end of 1998 might be a result of recent problems in the Czech Republic (OECD, 1998a). Table 1 also shows that investment in shares is highly correlated with investment in bonds, maybe with the exception of Russia. This suggests that the criteria for investment in shares might not be much different for investment in bonds.

\footnotetext{
${ }^{8}$ This number is only a lower bound because not all respondents wanted to answer on this item.

${ }^{9}$ For grading only 20 criteria were given. The catalogue of criteria to be graded was also changed a little to maximize the information on the financial markets (see Appendix). Since our respondents are experts in financial markets, information on these criteria will be of particularly high value.

${ }^{10}$ Only a very small fraction of total capital invested in Central and Eastern Europe was not invested in any of the six countries covered in this study.
} 
Therefore the results of this study which focuses on the stock markets and their institutional settings should also be relevant for the bond markets. ${ }^{11}$

\subsection{Relevance of the Criteria}

The survey participants were asked to rank each criterion according to its relevance for their investment decisions. Table 2 lists the criteria by their degree of importance as assigned by the respondents.

\section{Table 2: Most Important Criteria for Portfolio Investment Decisions}

\begin{tabular}{|c|c|}
\hline Classification & Criteria \\
\hline General & $\begin{array}{ll}\text { - } & \text { Stability of legal system }(83 \%) \\
\text { - } & \text { Stability of financial system }(81 \%) \\
\text { - } & \text { Stability of political system }(78 \%) \\
\text { - } & \text { Currency stability }(68 \%) \\
\text { - } & \text { Clear tax legislation }(63 \%) \\
\text { - } & \text { General economic situation }(62 \%) \\
\text { - } & \text { Strictness of bankruptcy laws }(59 \%)\end{array}$ \\
\hline Microeconomic & $\begin{array}{ll}\text { - } & \text { Managerial qualification }(93 \%) \\
\text { - } & \text { Productivity of the investment target }(83 \%) \\
\text { - } & \text { Growth of the particular sector }(83 \%) \\
\text { - } & \text { Skill level of employees of the investment target }(65 \%) \\
\text { - } & \text { Personal contacts with management }(65 \%) \\
\text { - } & \text { Level of taxation of the investment target }(53 \%)\end{array}$ \\
\hline Financial Markets & $\begin{array}{ll}\text { - } & \text { Liquidity of the individual stocks }(97 \%) \\
\text { - } & \text { Legislation and enforcement of law }(83 \%) \\
\text { - } & \text { Controls on capital flow }(78 \%) \\
\text { - } & \text { Presence of strategic investors }(53 \%) \\
\text { - } & \text { Listing at a foreign exchange }(52 \%)\end{array}$ \\
\hline
\end{tabular}

Notes: Average degree of importance on a scale of 0-100 \% in brackets. The degree of importance is obtained by calculating the average over all responses on each criterion. Then the results are scaled to be in the range of $0 \%$ (unimportant) to $100 \%$ (very important). Less important criteria are not tabled. The full questionnaire can be found in the Appendix.

Table 2 shows that institutional investors check a whole range of criteria before they buy assets in a CEE country. Macro- and microeconomic criteria are important as well as the general political environment and the institutional setting of financial markets.

On a scale of 0-100 percent, liquidity of the individual stock is - on average - the most important factor for the investors (97 percent). Crucial is also managerial qualification (93 percent) and stability of the legal (83 percent) and the financial system ( 81 percent). Less relevant are, for example, low inflation (51 percent), low government debt (49 percent), a low

\footnotetext{
${ }^{11}$ We will come back to this aspect in our concluding remarks.
} 
share of state ownership in the investment target (45 percent) and the presence of other institutional investors (43 percent).

On the microeconomic side, portfolio investors look for highly qualified management teams. Particularly in the former centrally planned economies this is a crucial factor because the economic environment is still changing rapidly. Competent decisions regarding the allocation of capital and labor are needed (Frydman et al., 1997). But also productivity and growth are essential. From the financial market perspective, liquidity of the individual stock is the dominant criterion. Institutional investors like investment funds generally have a strong preference for liquid assets (Blommestein, 1998). In Central and Eastern Europe this might be of particular relevance because in some countries ${ }^{12}$ exit from the investment is hindered by special rules. At the same time they demand clear and fair legislation. As non-domestic investors they must rely on the complete enforcement of law. Otherwise they face a strong disadvantage compared with domestic investors.

\subsection{Country Performance on the Criteria}

The respondents were also asked to assign each of the six countries a grade on all criteria. Table 3 gives the average grade each country received in the three main categories. Thereby a grade of 1.00 means "excellent" and a grade of 6.00 means "failed". 13

Table 3: General Assessment of the CEE countries

\begin{tabular}{lrrrrrr}
\hline & $\begin{array}{r}\text { Czech } \\
\text { Republic }\end{array}$ & Hungary & Poland & Estonia & Slovenia & Russia \\
\hline General and Macroeconomic & 3.88 & 2.07 & 2.27 & 2.44 & 2.58 & 5.84 \\
Microeconomic & 4.06 & 2.50 & 3.40 & 2.93 & 3.08 & 4.67 \\
Financial Markets & 3.57 & 2.23 & 2.51 & 3.11 & 4.05 & 5.01 \\
\hline Mean & 3.84 & 2.27 & 2.73 & 2.83 & 3.24 & 5.17 \\
Number of observations & 21 & 21 & 21 & 21 & 21 & 21 \\
\hline
\end{tabular}

Notes: Average grades received on a scale from 1 (excellent) to 6 (failed), weighted by the importance of each criterion as stated by the respondents. For details on the content of each category see below.

The general assessment suggests that no CEE country is an excellent investment target from the perspective of foreign portfolio investors. Among the five EU candidates, Hungary per-

\footnotetext{
${ }^{12}$ For example, investors in Slovenia cannot sell any amount of equity instantaneously. In addition, since early 1997 foreign exchange flows must go through client accounts opened in banks with full banking licenses (OECD, 1997c: 87).

${ }^{13}$ The grades on each criterion are weighted by the relative importance as stated by the respondents (Table 2). However, without weighting very similar results were obtained.
} 
forms best with an average of 2.27, the Czech Republic worst with an average of 3.84. The very bad grades that Russia received in all three categories stresses the fact that there is still a large discrepancy to the EU candidates. Russia should therefore be regarded as a special case.

With the exception of the Czech Republic the EU candidates have only minor problems in the political and macroeconomic sphere. Problems seem to be more severe on the microeconomic side and in the institutional framework of financial markets. To get a more detailed picture of the current problems in CEE countries we look at the individual criteria in the next section (Tables 4-6).

Table 4: Macroeconomic Criteria

\begin{tabular}{lrccccc}
\hline & $\begin{array}{c}\text { Czech } \\
\text { Republic }\end{array}$ & Hungary & Poland & Estonia & Slovenia & Russia \\
\hline Stability of legal system & 3.50 & 2.32 & 2.81 & 2.25 & 3.34 & 5.72 \\
Stability of financial system & 3.64 & 1.69 & 1.56 & 2.25 & 2.25 & 6.00 \\
Stability of political system & 3.37 & 1.79 & 2.18 & 2.67 & 2.03 & 5.74 \\
General economic situation & 4.55 & 2.47 & 2.05 & 2.83 & 2.47 & 5.87 \\
Bankruptcy law & 4.68 & 2.25 & 2.91 & 2.25 & 2.92 & 5.85 \\
\hline Weighted average & 3.88 & 2.07 & 2.27 & 2.44 & 2.58 & 5.84 \\
\hline
\end{tabular}

Notes: The criteria are ranked by their importance as stated by the respondents.

Stability of the legal, political and financial system seems to be sufficient in Hungary, Poland, Estonia and Slovenia. In general, the continuous process of transforming communist countries into market economies seems to be a success. Good grades on the macroeconomic situation support this notion. The most important criterion for the investors, stability of the legal system, appears to be slightly weaker in the Czech Republic and Slovenia. Striking are the generally worse grades of the Czech Republic compared to the other four EU candidates. The hopeless grades on Russia seem to preclude any investment in that country.

Among the five EU candidates, the general economic situation which encompasses inflation, economic growth and other macroeconomic indicators is also comparatively weak in the Czech Republic. The current state of the Czech and Russian bankruptcy laws which are of central importance in times of major industrial restructuring like in CEE countries provoke dissatisfaction among the investors. Overinvestment and a low rate of firm exits might be a consequence of this still not acceptable Czech bankruptcy law (OECD, 1998a). Some improvements in the legal system and in particular on the bankruptcy codes seem possible in Poland and Estonia as well. 
Russia fails in almost all criteria. While problems with the Russian political and financial system are indeed significant, ${ }^{14}$ the bad grades might heavily be influenced by the Russian Ruble crises in 1998.

Table 5: Microeconomic Criteria

\begin{tabular}{lrrrrrr}
\hline & $\begin{array}{r}\text { Czech } \\
\text { Republic }\end{array}$ & Hungary & Poland & Estonia & Slovenia & Russia \\
\hline Managerial Qualification & 4.82 & 2.32 & 3.65 & 3.50 & 2.92 & 4.97 \\
Productivity & 5.03 & 3.08 & 4.33 & 3.14 & 3.86 & 5.72 \\
Competitive Pressure & 4.09 & 2.47 & 3.06 & 2.73 & 3.14 & 4.38 \\
Skill level of workers & 2.47 & 2.25 & 2.62 & 2.35 & 2.17 & 3.35 \\
Level of Effective Taxation & 3.08 & 2.25 & 2.94 & 2.61 & 3.17 & 4.47 \\
\hline Weighted average & 4.06 & 2.50 & 3.40 & 2.93 & 3.08 & 4.67 \\
\hline
\end{tabular}

Notes: The criteria are ranked by their importance as stated by the respondents.

A more diverse picture can be found on the microeconomic side (Table 5). Managerial qualification, the on average most relevant criterion, is the best in Hungary and to a lower extent in Slovenia. This might be a result of relatively weaker political interference under the communist regimes in both of these two countries. In contrast, Czech and Russian managers seem to be only poorly qualified to govern enterprises in times of major restructuring. Likewise, productivity as a determinant of the rate of return is judged as low in the Czech Republic, Russia and also in Poland.

Competition in the product markets is often regarded as a driving factor for productivity. ${ }^{15}$ Empirical evidence is also accumulating. For Germany Januszewski et al. (1999) show that firms operating in industries which are characterized by more intensive product market competition tend to see higher rates of productivity growth. Nickell et al. (1997) provide similar results for the United Kingdom. Currently the intensity of competition is graded as "good" at best in the CEE countries. But in light of EU accession and the perspective of the Common Market we can expect significant improvements here.

In contrast, workers seem to be well skilled in all CEE countries. Even in Russia the skill level of workers is graded with 3.34. Taxation as a factor of minor importance for the investment decision seems to be sufficiently low in Poland, Hungary and in Estonia. But improvements are demanded for the Czech Republic, Slovenia and especially for Russia.

\footnotetext{
${ }^{14}$ See OECD (1997b) for an extensive survey.

${ }^{15}$ See for example Hart (1983) and Hermalin (1992) for theoretical models.
} 
Table 6: Financial Market Criteria ${ }^{1}$

\begin{tabular}{|c|c|c|c|c|c|c|}
\hline & $\begin{array}{r}\text { Czech } \\
\text { Republic }\end{array}$ & Hungary & Poland & Estonia & Slovenia & Russia \\
\hline Liquidity & 5.08 & 2.97 & 3.24 & 5.53 & 5.53 & 4.55 \\
\hline Control on flows of capital & 1.66 & 1.88 & 2.18 & 1.83 & 3.79 & 4.95 \\
\hline Enforcement of law & 3.66 & 2.09 & 2.25 & 2.04 & 2.25 & 5.53 \\
\hline $\begin{array}{l}\text { Treatment domestic vs. for- } \\
\text { eign investors }\end{array}$ & 3.50 & 1.63 & 2.09 & 2.25 & 4.54 & 5.12 \\
\hline Weighted average $^{2}$ & 3.57 & 2.23 & 2.51 & 3.11 & 4.05 & 5.01 \\
\hline Listing requirements & 3.79 & 2.18 & 2.47 & 2.92 & 3.31 & 4.68 \\
\hline Clearing and settlement & 2.18 & 1.44 & 1.88 & 1.89 & 3.86 & 4.68 \\
\hline $\begin{array}{l}\text { Protection of minority share- } \\
\text { holders }\end{array}$ & 4.75 & 2.88 & 3.97 & 2.67 & 3.92 & 5.26 \\
\hline Disclosure requirements & 3.50 & 1.78 & 2.09 & 3.08 & 3.92 & 4.91 \\
\hline Trading supervision & 4.44 & 2.72 & 2.72 & 3.08 & 4.08 & 5.22 \\
\hline Regulation of privatization & 4.95 & 1.92 & 2.32 & 2.56 & 2.88 & 5.21 \\
\hline Unweighted average $^{3}$ & 3.93 & 2.15 & 2.57 & 2.70 & 3.66 & 4.99 \\
\hline
\end{tabular}

Notes: ${ }^{1}$ In the first part of the table criteria are ranked by their importance as stated by the respondents, in the second part randomly. ${ }^{2}$ Weighted average of the first four criteria. ${ }^{3}$ Unweighted average of all criteria.

Special attention was given to financial market criteria because our respondents are experts in this field. Table 6 consists of two parts: the first part contains the grades on the criteria which were ranked by the fund managers according to the relevance for their investment decisions. The second part contains the grades on additional criteria which were not ranked by the fund managers. ${ }^{16}$ The overall result is that Hungary and Poland seem to have the least problems in their financial markets, whereas problems are again largest in Russia.

Looking at liquidity which was stated to be of highest importance none of the CEE countries is a good investment target. Even Hungary and Poland performing the best on this criterion receive only grades of 2.97 and 3.24 respectively. While the fraction of free-floating shares is quite high, for example in large Polish and Slovenian firms listed on the stock exchange, ${ }^{17}$ market capitalization and turnover in all CEE countries is still low compared to Western economies (FIBV, 1999). ${ }^{18}$ In addition, instantaneous exit from investment is often barred by

\footnotetext{
${ }^{16}$ As can be seen from Table 6, the weighted results are not much different from the unweighted results.

${ }^{17}$ See Budapest Business Journal (1999) for details on the company ownership structures in CEE countries.

${ }^{18}$ For example, at the end of 1998 stock market capitalization as a percentage of GDP was 51.3 percent at the Frankfurt stock exchange, but only 28.9 percent in Hungary and 13.7 percent in Poland (FIBV, 1999).
} 
particular rules which increase transaction costs (e.g. the requirement to channel foreign exchange flows through client accounts in domestic banks).

In contrast, a functioning institutional framework seems (at least partially) to be in place. For example, an efficient system of clearing and settlement, strict listing requirements and fair treatment of domestic versus foreign investors can be found in Hungary, Poland and Estonia. Major deficits are recorded for the Czech Republic and Slovenia regarding the protection of minority shareholders which Western investment funds usually are. ${ }^{19}$ For the Czech Republic, for example, cases of open fraud through insider trading are reported that violate minority rights severely (OECD, 1998a). But also the still high stake of the government in Czech, Polish and Slovenian firms could explain the bad grades on this criterion.

Finally, the portfolio investors want to see improvements in trading supervision and in the treatment of foreign versus domestic investors in particular in the Czech Republic and Slovenia. But also Czech regulation of privatization seems to have major deficits. This result contrasts with the situation at the beginning of the 1990s when the Czech Republic served as the ideal case of privatizing a formerly communist economy.

What can be learned from this section is that Western portfolio managers check a whole catalogue of criteria when they consider to invest in a CEE country. Liquidity of the individual stock emerges as the most important criterion. But also managerial qualification, a precondition for an appropriate return on investment, and stability of the political, legal and financial systems, determinants of the general risk of the investment, are important. The detailed analysis shows that all CEE countries have their specific problems. But generally, Hungary and Poland emerge as the relatively best-performing countries. This is consistent with the quantitative importance of Hungarian and Polish assets in the Western portfolios. Vice versa, the smaller fraction of Czech and Russian assets in the portfolios might reflect the relatively bad grades these economies achieved. Section 4 will analyze this issue quantitatively.

\section{Empirical Results}

This section attempts to identify the driving factors of portfolio investment in the CEE countries. Formally speaking, the endogenous variable is the fraction of shares each fund holds in each of the six CEE countries. Exogenous variables are the country-specific grades on each criterion as assigned by each fund manager. We therefore estimate the following Model 1:

\footnotetext{
${ }^{19}$ Survey participants report that they hold an average size of only 0.5-1 percent of outstanding shares.
} 


$$
\mathrm{y}_{\mathrm{it}}=\alpha+\sum_{\mathrm{j}=1}^{\mathrm{J}} \beta_{\mathrm{j}} \mathrm{x}_{\mathrm{ijt}}+\varepsilon_{\mathrm{it}}
$$

for $\mathrm{i}=1, \ldots, \mathrm{I}$ and $\mathrm{t}=\mathrm{CZ}, \mathrm{H}, \mathrm{PL}, \mathrm{EST}, \mathrm{SLO}$ and RUS.

Hereby, $y_{\text {it }}$ represents the fraction of shares held by investor $\mathrm{i}$ in country $\mathrm{t}$. In Model 1 the intercept $\alpha$ is assumed to be constant over all six equations but this assumption will be dropped below. Each $y_{i t}$ is explained by a set of $J$ exogenous variables. The coefficients $\beta$ are assumed to be constant over all six countries. Hence, one equation is estimated for all six countries. This assumption is also dropped in Model 2:

$$
y_{i t}=\alpha_{t}+\sum_{j=1}^{J} \beta_{j t} x_{i j t}+\varepsilon_{i t}
$$

for $\mathrm{i}=1, \ldots, \mathrm{I}$ and $\mathrm{t}=\mathrm{CZ}, \mathrm{H}, \mathrm{PL}, \mathrm{EST}, \mathrm{SLO}$ and RUS.

In Model 2, the intercept $\alpha$ and the coefficients may vary from country to country. This is appropriate when the exogenous variables influence the endogenous variable differently from country to country. Hence, one equation for each country will be estimated in Model 2.

\subsection{Construction of the Exogenous Variables}

Our data on grades are in discrete form because respondents had to choose between "1" (severe problems), "2" (problems, but not severe) and "3" (no problems) for each criterion. Therefore, variation in the exogenous variables cannot be large. Looking at the aggregate grading data given in Tables 4-6 we suspect that the grading data might be highly collinear. This requires to reduce the number of exogenous variables. The crucial question is what exogenous variables to use in the regression model.

We follow a two-way approach: First, we will make use only of those exogenous variables which are - on average - the most relevant from the perspective of the investors. Second, we conduct a principal factor analysis (PFA) using the data on grades to construct a small number of factors which (econometrically) explain the endogenous variables best.

For the first approach we inspect the data concerning the relevance of each criterion for investment. Sorting all criteria by category and by their degree of relevance as assigned by the respondents singles out the following criteria: ${ }^{20}$

\footnotetext{
${ }^{20}$ See Table 2.
} 
- Stability of the legal system

- Competence of management

- Liquidity of the individual stock

We chose to select one criterion from each category because the categories are supposed to catch different aspects of the investment decision. Stability of the legal system describes the general risk associated with an investment, competence of management the return to be expected whereas liquidity is the third characteristic that is generally checked for investment decisions (Steiger, 2000). ${ }^{21}$

As exogenous variables six dummies are calculated according to the following definitions:

$D_{i j t}=1$ for $j=1,2,3$ when investor $i$ assigns the best grade " 3 " to country $t$ on the three criteria listed above respectively, and zero otherwise,

$D_{i j t}=1$ for $\mathrm{j}=4,5,6$ when investor $\mathrm{i}$ assigns the worst grade " 1 " to country t on the three criteria listed above respectively, and zero otherwise.

The reference category for each variable is therefore the grade " 2 ".

For the second approach we conduct a principal factor analysis (PFA) using the data on grades. PFA goes back to Spearman (1904). The idea is to find a small number of J common factors that linearly construct the $\mathrm{N}$ original variables (with $\mathrm{N}>\mathrm{J}$ ) such that the common factors are orthogonal to each other. ${ }^{22}$ Thus PFA is particularly suitable to data that are highly collinear as in our case. Formally speaking, $\mathrm{J}$ new variables (our exogenous variables) are calculated by estimating these common factors and their weights (their "loading") in an iterative maximum likelihood procedure. ${ }^{23}$ To put it more intuitively, PFA tries to detect a small number of hypothetical factors that determine the endogenous variable but are empirically unobservable. They 'explain' the observable exogenous variables. In our case, PFA boils

\footnotetext{
${ }^{21}$ These three criteria are not country-specific because investors' criteria are assumed to be invariant to the country they chose to invest in. The same reasoning applies to the second approach of selecting exogenous variables.

${ }^{22}$ The approach of PFA is different from principal component analysis (PCA) since PCA selects those variables which have the highest variance and thus best explain total variance. We prefer PFA here because we do not know exactly whether we checked all relevant criteria in the survey.

${ }^{23}$ A detailed description of the technique applied in PFA can be found in Ost (1984: $575 \mathrm{ff}$.).
} 
down the 20 initial grading variables to only three common factors. ${ }^{24}$ Table 7 shows which initial variables are grouped together in common factors when PFA is performed.

\section{Table 7: Composition of the Common Factors}

\begin{tabular}{|c|c|c|}
\hline Factor 1: General Risk & Factor 2: Return Potential & Factor 3: Institutional Risk \\
\hline $\begin{array}{l}\text { - } \\
\text { - }\end{array}$ & $\begin{array}{ll}\text { - } & \text { Productivity } \\
\text { - } & \text { Protection of minority share- } \\
\text { holders } \\
\text { - } & \text { Regulation of privatization } \\
\text { - } & \text { Management competence } \\
\text { - } & \text { Quality of bankruptcy law } \\
\text { - } & \text { Enforcement of law }\end{array}$ & $\begin{array}{l}\text { - } \text { Clearing \& Settlement } \\
\text { - Treatment of domestic vs. } \\
\text { foreign investors } \\
\text { - } \quad \text { Disclosure rules } \\
\text { - Control on capital flows }\end{array}$ \\
\hline
\end{tabular}

Notes: The variables are ranked by the size of their loading. Only variables with a loading above 0.60 were considered.

The composition of variables is quite diverse for the second, but not for the first and third common factor. Looking at the individual variables factor 1 may be labeled "General Risk" because the variables measure how risky the political and economic environment is. Factor 3 consists of variables which describe the institutional setting of financial markets. It might therefore summarize the "Institutional Risk" in a particular country. ${ }^{25}$ Factor 2 contains a variety of variables. But especially productivity and managerial competence which determine the return of an investment receive high loading factors. Efficient privatization also has a high loading. It is a prerequisite for a sufficient number of privatized firms that offer reasonable returns on an investment. Therefore we label this factor "Return Potential".

\subsection{Regression Results}

One objective of this study is to explain the portfolio structure of Western fund managers investing in CEE countries. Table 8 presents the results from OLS regressions estimated with Model 1. Coefficients are assumed to be constant across all countries.

\footnotetext{
${ }^{24}$ A minimum value of 1.00 was required for the individual Eigenvalues. This is a commonly applied critical value. All calculations were performed with STATA 6.0.

${ }^{25}$ Note that stock market liquidity is not detected by PFA as a relevant variable in any of the three common factors. This is mainly due to the low variation of grades on this criterion.
} 


\begin{tabular}{lrr}
\hline & Coefficient (Std. Err.) & Coefficient (Std. Err.) \\
\hline Constant & $16.990^{* *}(3.670)$ & $17.860^{* * *}(1.948)$ \\
Dummy $_{1}$ : Stability of legal system (+) & $8.503^{* *}(3.812)$ & -- \\
Dummy $_{2}$ : Management Competence (+) & $7.210^{*}(4.210)$ & -- \\
Dummy $_{3}$ : Stock Market Liquidity (+) & $8.711(5.718)$ & -- \\
Dummy : Stability of legal system (-) & $-1.732(4.379)$ & -- \\
Dummy $:$ Management Competence (-) & $4.319(3.769)$ & -- \\
Dummy $_{6}$ : Stock Market Liquidity (-) & $-15.476^{* *}(3.308)$ & -- \\
General Risk & -- & $2.621(2.140)$ \\
Return Potential & -- & $2.934(2.042)$ \\
Institutional Risk & -- & $5.589^{* *}(2.121)$ \\
\hline Number of Observations & 76 & 65 \\
Adjusted $R^{2}$ & $39.74 \%$ & $11.64 \%$ \\
\hline
\end{tabular}

Notes: Standard errors in parentheses. Significance levels of 5\% (**) and 10\% (*) respectively were used. (+) indicates the dummies for the positive influence and (-) the dummies for the negative influence respectively (see definitions above).

We see from Table 8 that the fraction of assets held by a fund manager in a particular country is significantly influenced by specific criteria. Looking at the results from the first specification of the exogenous variables (second column) we find that fund managers who think that a country has a high stability of its legal system increase their investment by 8.5 percent on average. Likewise, when a fund manager thinks that stock market liquidity in a particular country is low he/she decreases investment by - on average - 15.5 percent. Competence of management also has a positive influence, but is significant only on the 10 percent level.

The results from our second specification of the exogenous variables (third column) look similar. All three common factors have a positive influence on the fraction of assets held in a particular country. However, only a low degree of institutional risk in the financial markets increases fund managers' investment significantly. Comparing the results from the two specifications we see that the explanatory power of the first specification (adj. $R^{2}=39.74$ percent) is much higher than for the second specification (adj. $R^{2}=11.64$ percent). This may be due to the higher number of observations in the first specification $(\mathrm{N}=76)$ because less variables must jointly not contain any missing values. Overall, OLS regression results support the hypothesis that decisions on portfolio investment are guided by specific criteria. Ceteris paribus, im- 
provements on these criteria from the side of a CEE country could therefore contribute to higher foreign portfolio investment in that country.

Since about 20 percent of the observations on the endogenous variable have the value zero, we also ran a Tobit model. ${ }^{26}$ Tobit models correct for a potential bias in the estimated coefficients due to censored data. In our case, data are left-censored with the value zero. However, significance of coefficients shows to be robust in the Tobit estimation; coefficients slightly increase in absolute value.

The next step in our analysis is to check whether coefficients are country-specific, i.e. if Model 2 might be more appropriate instead of Model 1. This is accomplished by constructing a SURE model as formulated by Zellner (1962). We estimate a system of six seemingly unrelated regressions (SURE) and obtain the variance-covariance matrix of all coefficients and all residuals. This allows us to perform joint tests on coefficients. Additionally, if the error terms from all six countries were correlated, estimating six country-specific equations separately would be inefficient. The SURE model addresses this problem by estimating the six equations simultaneously with a GLS approach. ${ }^{27}$

Before we look at the estimation results from the SURE model we check whether the error terms are correlated in our sample, i.e. if SURE is necessary. The test developed by Breusch and Pagan (1980) is appropriate here. Applying the Breusch-Pagan test to the first specification we cannot reject the independence of the six equations at the 10 percent level, whereas for the second specification independence is rejected at the 5 percent level. This suggests that the six equations should be estimated jointly in a SURE model when the PFA results are used as exogenous variables. In turn, six separate regressions can be run in the case of the first specification using simple OLS models. It must be noted here that the number of cases in the second specification is very low $(\mathrm{N}=48)$ because a missing value in any of the 20 original variables will cause a whole observation to be dropped. Since efficiency of estimation is a large sample property the result from the Breusch-Pagan test should be interpreted with some caution.

A second indicator on the necessity of estimating the six equations jointly in a SURE model provide the joint tests of coefficients as displayed in Table 9.

\footnotetext{
${ }^{26}$ See Tobin (1958) for the econometric technique applied in this estimation procedure.

${ }^{27}$ See Greene (1997: 674-703) for a formal description of the feasible generalized least squares technique applied in SURE models.
} 
Table 9: Joint Tests on Country-Specific Coefficients (SURE Model)

\begin{tabular}{|c|c|c|c|c|}
\hline \multirow[t]{2}{*}{ Specification } & \multicolumn{2}{|c|}{ (1) Six Dummy Variables } & \multicolumn{2}{|c|}{$\begin{array}{r}\text { (2) Three Common Factors } \\
\text { from PFA }\end{array}$} \\
\hline & F-Test & Level of Sign. & F-Test & Level of Sign. \\
\hline Constant & 301.80 & 0.0000 & 269.90 & 0.000 \\
\hline Dummy $_{1}$ : Stability of legal system (+) & 43.50 & 0.0000 & -- & -- \\
\hline Dummy $_{2}$ : Management Competence (+) & 20.97 & 0.0008 & -- & -- \\
\hline Dummy $_{3}:$ Stock Market Liquidity (+) & 7.77 & 0.0206 & -- & -- \\
\hline Dummy $_{4}$ : Stability of legal system (-) & 14.75 & 0.0006 & -- & -- \\
\hline Dummy ${ }_{5}$ : Management Competence (-) & 11.23 & 0.0470 & -- & -- \\
\hline Dummy 6 : Stock Market Liquidity (-) & 78.88 & 0.0000 & -- & -- \\
\hline General Risk & -- & -- & 4.23 & 0.5164 \\
\hline Return Potential & -- & -- & 3.93 & 0.5601 \\
\hline Institutional Risk & -- & -- & 16.66 & 0.0052 \\
\hline Number of Observations & & 54 & & 48 \\
\hline
\end{tabular}

Notes: Due to collinearity of some exogenous variables some constraints need to be dropped in the joint tests. As a consequence the critical values of the F-tests are not constant over all tests. Therefore the levels of significance are displayed additionally. See also footnotes of Table 8.

The hypothesis that the coefficients on the six dummy variables as used in the first specification are equal across all six countries can be rejected on a very high level of significance. This confirms that a separate regression should be run for each country. For the second specification, equality of the coefficients cannot be rejected for the variables general risk and return potential. Econometrically this means that only the coefficient on institutional risk varies significantly between the six countries. Economically this means that investors tend to generate their investment decisions according to the same criteria across all six countries. Only institutional risk seems to have a country-specific influence on investment.

Table 10 and Table 11, respectively, present the results from OLS country-specific regressions for the first specification and from the SURE model for the second specification. 
Table 10: Country-Specific Coefficients (OLS, six dummies as exogenous variables)

\begin{tabular}{|c|c|c|c|c|c|c|}
\hline & $\begin{array}{r}\text { Czech Re- } \\
\text { public }\end{array}$ & Hungary & Poland & Estonia & Slovenia & Russia \\
\hline Constant & $\begin{array}{c}40.739^{* *} \\
(4.800)\end{array}$ & $\begin{array}{c}20.597^{* *} \\
(6.259)\end{array}$ & $\begin{array}{c}23.245^{* *} \\
(8.872)\end{array}$ & $\begin{array}{r}1.893 \\
(1.224)\end{array}$ & $\begin{array}{l}5.695^{* *} \\
(1.453)\end{array}$ & $\begin{array}{r}22.581^{* *} \\
(6.897)\end{array}$ \\
\hline Stability of legal system (+) & $\begin{array}{r}10.224 \\
(5.615)\end{array}$ & $\begin{array}{c}19.140^{* *} \\
(6.300)\end{array}$ & $\begin{array}{r}11.977 \\
(8.731)\end{array}$ & $\begin{array}{r}1.340 \\
(1.499)\end{array}$ & $\begin{array}{r}-1.695 \\
(0.951)\end{array}$ & dropped \\
\hline Management Competence (+) & $\begin{array}{c}-34.401^{* *} \\
(11.567)\end{array}$ & $\begin{array}{r}4.422 \\
(5.513)\end{array}$ & $\begin{array}{r}3.326 \\
(8.919)\end{array}$ & $\begin{array}{r}-0.144 \\
(1.836)\end{array}$ & $\begin{array}{r}-1.316 \\
(1.098)\end{array}$ & $\begin{array}{r}-8.036 \\
(13.795)\end{array}$ \\
\hline Stock Market Liquidity (+) & dropped & $\begin{array}{r}-2.321 \\
(5.534)\end{array}$ & $\begin{array}{r}1.350 \\
(8.731)\end{array}$ & dropped & dropped & dropped \\
\hline Stability of legal system (-) & $\begin{array}{r}5.278 \\
(4.885)\end{array}$ & dropped & dropped & dropped & dropped & dropped \\
\hline Management Competence (-) & $\begin{array}{r}-32.983^{* *} \\
(7.210)\end{array}$ & $\begin{array}{r}-9.334 \\
(7.754)\end{array}$ & $\begin{array}{r}-3.811 \\
(8.491)\end{array}$ & $\begin{array}{r}-0.296 \\
(2.290)\end{array}$ & $\begin{array}{r}0.001 \\
(1.228)\end{array}$ & $\begin{array}{r}-16.609^{*} \\
(8.725)\end{array}$ \\
\hline Stock Market Liquidity (-) & $\begin{array}{r}2.021 \\
(5.539)\end{array}$ & dropped & $\begin{array}{r}18.589 \\
(14.102)\end{array}$ & $\begin{array}{r}-1.597 \\
(1.499)\end{array}$ & $\begin{array}{c}-4.000^{* *} \\
(1.228)\end{array}$ & $\begin{array}{r}4.523 \\
(7.556)\end{array}$ \\
\hline Number of Observations & 14 & 14 & 14 & 10 & 10 & 14 \\
\hline
\end{tabular}

Notes: Standard errors in parentheses. Significance levels of 5\% (**) and $10 \%(*)$ respectively were used. 'Dropped' means that the particular variable was dropped from the regression due to high collinearity with another variable.

As to be expected, when fund mangers think that a country performs well on a specific criterion they - on average - increase investment. In turn, they mostly decrease investment when a country fails to fulfill their expectations. But, as Table 10 shows, these effects are often not significantly different from zero.

Table 10 suggests that Hungarian assets are increased significantly by over 19 percent because investors believe that Hungary has a very stable legal system - a precondition for portfolio investment according to the investors. None of the five other CEE countries exhibits this effect. In the case of Slovenia, low liquidity of the stock market appears to be damaging to investment (-4 percent). For the Czech Republic (-33.0 percent) and Russia (-16.6 percent) we observe that low managerial competence seems to decrease investment significantly. But we also find that those investors who believe that Czech management is competent hold a by about 34 percent lower fraction of Czech assets. This counterintuitive result is due to an outlier. Inspecting the data shows that one single investor grades Czech management as highly 
competent but at the same time holds only a very small fraction of Czech shares in the portfolio. ${ }^{28}$

The coefficient of the intercept measures the average fraction of a particular country as owned by the reference category. Comparing the estimated coefficients with Table 1 suggests that in practice the average investor does not belong to the reference category and that the intercept coefficient should therefore not be interpreted further. ${ }^{29}$

A number of variables had to be dropped from the OLS estimation procedure as can also be seen from Table 10. This is a result of high collinearity among the exogenous variables. To address this problem PFA was conducted. Results from the SURE model with the common factors as obtained through PFA estimation are as follows:

Table 11: Country-Specific Coefficients (SURE, exogenous variables from PFA)

\begin{tabular}{lrrrrrr} 
& $\begin{array}{r}\text { Czech } \\
\text { Republic }\end{array}$ & Hungary & Poland & Estonia & Slovenia & Russia \\
\hline Constant & $14.871^{* *}$ & $30.204^{* *}$ & $36.883^{* *}$ & 0.815 & 0.696 & 11.839 \\
& $(2.265)$ & $(5.208)$ & $(3.825)$ & $(0.468)$ & $(0.856)$ & $(10.109)$ \\
General Risk & 1.094 & 2.319 & 3.355 & -0.679 & -0.367 & 1.733 \\
& $(1.742)$ & $(3.530)$ & $(3.340)$ & $(0.446)$ & $(0.867)$ & $(8.859)$ \\
Return Potential & 2.388 & 4.860 & -0.665 & $1.087^{* *}$ & $1.845^{* *}$ & 4.203 \\
& $(1.467)$ & $(3.060)$ & $(2.070)$ & $(0.316)$ & $(0.867)$ & $(4.451)$ \\
Institutional Risk & $-4.755^{* *}$ & $6.095^{* *}$ & 0.833 & -0.252 & 0.289 & -2.090 \\
& $(2.271)$ & $(2.319)$ & $(3.096)$ & $(0.312)$ & $(0.420)$ & $(2.036)$ \\
Number of Observations & 8 & 8 & 8 & 8 & 8 & 8 \\
\hline
\end{tabular}

Notes: Standard errors in parentheses. Significance levels of 5\% (**) and 10\% (*) respectively were used.

Table 11 presents regression results from the SURE model which estimated the six countryspecific equations simultaneously. The advantage of eliminating the existing correlation between the error terms and of capturing all variables in three orthogonal exogenous variables comes at a significant cost: the number of observations with no missing values decreases to 8 per equation. The reason is that 13 out of the total 21 observations had missing values on one or more items checked in the survey.

The tests performed above (Table 9) suggested that the coefficients on general risk and return potential do not differ significantly across the countries. We therefore tested additionally if

\footnotetext{
${ }^{28}$ The significance of coefficients did not change when Tobit models were estimated instead; estimated coefficients increased slightly in absolute value. In addition, only for Poland we find a positive influence of legal stability on the 10 percent-level of significance.

${ }^{29}$ In addition, the intercept catches the average value of any missing variables.
} 
these coefficients are significantly different from zero. For the coefficient on general risk we find that it is not significantly different from zero on the 10 percent-level, whereas the coefficient on return potential is larger than zero on the 1 percent-level. This means that factors like high productivity, managerial competence and growth significantly contribute to higher investment. In particular, investment in Estonia ( +1.1 percent) and Slovenia $(+1.8$ percent $)$ is significantly higher due to a good return potential.

The joint tests as displayed in Table 9 also suggested that the influence of institutional risk is country-specific. This is confirmed by the results in Table 11. The degree of institutional risk, i.e. the risk of a lower return as a result of poor clearing and settlement, unfair treatment of domestic versus foreign investors or controls on capital flows has a country-specific influence on investment. The fraction of assets invested in Poland, Estonia, Slovenia and Russia is not significantly influenced by the degree of institutional risk. But Hungary was able to attract significantly higher investment due to a high quality of financial market rules that helped investors to trust in the prospects of the Hungarian economy. In turn, in the Czech Republic a higher quality of financial market rules seems to decrease investment. This counterintuitive result is again caused by an outlier: one investor holding a very high fraction of Czech assets assigned a very bad grade to the rules in the Czech financial market.

In contrast to the results in Table 10, the intercept coefficient in Table 11 can be interpreted as the average fraction of shares held in a particular country by all investors. The reason is that PFA produces normally distributed common factors. Comparing the estimated coefficients with Table 1 confirms this reasoning.

Taking together all results, we find that the CEE portfolio structure of Western investment funds can be explained by specific criteria. In particular, a stable legal system, high managerial competence and sufficient liquidity in the stock market all contribute to higher portfolio investment. Considering more than these three criteria does not improve the explanatory power of our model but stresses the importance of financial market rules (Table 8). Differentiating by country shows that in Hungary the stability of the legal system primarily drives investment (Table 10). In turn, low managerial competence limits investment in the Czech Republic and Russia, low stock market liquidity hinders investment in Slovenia. Using the grading data on all criteria we find that investment in the smaller economies of Estonia and Slovenia is primarily driven by a sound return potential (which, in turn, is based on managerial competence and high productivity) and by a high quality of financial markets rules in Hungary (e.g. fair treatment of foreign vs. domestic shareholders, efficient clearing and set- 
tlement). However, since the number of observations for the country-specific analyses is low, the latter results should be interpreted cautiously.

\section{Conclusions}

The intent of this study is two-fold: First, we want to know which factors determine portfolio investment in CEE countries, and second, how the current CEE portfolio structure of Western institutional investors can be explained.

We find that Western portfolio managers check a whole catalogue of criteria before they conduct investment in CEE countries. We identify three groups of criteria: the general risk of an investment which mainly is measured by stability of the financial and the legal system of a particular country. The return potential as the second group is determined by managerial competence, high productivity of the investment target but also by efficient regulation of privatization. Third, institutional risk is created by unfair treatment of domestic versus foreign shareholders, inefficient clearing and settlement and controls on capital flows. A criterion mentioned by almost all investors as very important is liquidity in the stock market. However, our principal factor analysis does not identify this criterion as important. ${ }^{30}$

The descriptive analysis shows that mainly a low return potential and a high risk from the institutional setting in the financial markets limits investment. According to survey respondents, the Czech Republic and Russia offer less qualified managers combined with reduced productivity and competitive pressure in the product markets. In the financial markets, investors are dissatisfied with Czech, Russian, but also with Slovenian and some specific Polish and Estonian rules. For example, protection of minority shareholders is regarded as "good" only in Hungary and Estonia. Especially for portfolio investors that hold only small stakes this is a crucial factor. Overall, Hungary emerges as the CEE country with the smallest problems, the Czech Republic and Russia with the largest problems.

Additionally, we conduct an econometric analysis to check the robustness of the descriptive results. Looking at regression results from the full sample (i.e. neglecting any country-specific effects) we find that the following characteristics support portfolio investment: stability of the legal system, managerial competence and a liquid stock market. Using the information on all other criteria we generally can confirm the relevance of these aspects.

\footnotetext{
${ }^{30}$ A reason for this might be that the variance in the grading data is very low on this item. PFA selects only those variables that have a relatively high variance.
} 
Running country-specific regressions instead we find that there is some evidence of heterogeneity between the countries. OLS regressions suggest that investment in Hungary is driven by stability of the legal system. In contrast, investment in the Czech Republic and Russia seems to be barred by low managerial competence, and low stock market liquidity in Slovenia. Estimating a system of six seemingly unrelated regressions (one for each of the six CEE countries) improves econometric efficiency of estimation but reduces the number of observations significantly. This approach indicates that investment is driven by a sound return potential in Estonia and Slovenia, and low institutional risk in Hungary. Overall, the main results from our descriptive analysis are confirmed by the econometric analysis: Hungary is most attractive to foreign portfolio investors, and the Czech Republic and Russia least attractive. A high quality of financial market rules, a liquid stock market, and a sound return potential support are important preconditions for high levels of portfolio investment.

Comparing the descriptive results with the results from the econometric analyses shows that both analytical methods can be used with our data. The advantage of the econometric approach is that the net effect of individual factors on portfolio investment can be calculated. We learn, for example, that investment in the smaller economies of Estonia and Slovenia is mainly driven by their potential for good returns. For the larger economies of Hungary and the Czech Republic the setting of the financial markets seems to be more relevant. However, all country-specific results are based on small samples and should therefore be interpreted with some caution.

This study points out several avenues for prospective future research. Since institutional investment is constantly increasing on a global scale and since CEE enterprises tend to rely more on equity finance than Western enterprises, the effects of Western portfolio investment should be analyzed more closely. Interesting could be a detailed analysis of the interaction of Western portfolio managers and CEE companies. Most survey respondents indicate that they are actively engaged in corporate governance in CEE firms. To our knowledge no study analyzed yet this shareholder activism in CEE companies. Empirical studies on US firms suggest that these activities can increase shareholder value. ${ }^{31}$

Another valuable extension of this study could be the analysis of investment in particular sectors to identify different degrees of risk. Likewise, the analysis of investors' assessments over time would be useful to identify the effect of changes in country-specific factors on port- 
folio investment. Finally, it could be interesting to incorporate push-factors that also can influence investment. This would not only require data on fund-specific liquidity or degree of competition in the fund industry but also a model on the allocation of capital between funds.

${ }^{31}$ See Black (1997), Karpoff (1998) and Del Guercio (1999) for comprehensive surveys of the empirical literature. 


\section{References}

Black, B. S. (1997), Shareholder Activism and Corporate Governance in the United States, Working Paper, Columbia University.

Blommestein, H. J. (1998), The New Financial Landscape and Its Impact on Corporate Governance, in: Morton Balling et al. (eds.), Corporate Governance, Financial Markets and Global Convergence, Dordrecht/NL.

Breusch, T. and A. Pagan (1980), The LM Test and Its Applications to Model Specification in Econometrics, Review of Economic Studies 47, 239-254.

Budapest Business Journal (1999), Equity Central Europe 1999, Budapest.

Del Guercio, D. and J. Hawkins (1999), The Motivation and Impact of Pension Fund Activism, Journal of Financial Economics 52, 293-340.

FIBV (1999), International Statistics on Stock Exchanges, http://www.fibv.com.

Frydman, R., C. Gray, M. Hessel and A. Rapaczynski (1997), Private Ownership and Corporate Performance: Some Lessons from Transition Economies, Working Paper, World Bank Development Research Group.

Greene, W. H. (1997), Econometric Analysis, Upper Saddle River/NJ.

Hart, O. D. (1983), The Market Mechanism as an Incentive Scheme, The Bell Journal of Economics 14 (2), 366-382.

Hermalin, B. E. (1992), The Effects of Competition on Executive Behavior, RAND Journal of Economics 23, 350-365.

IMF (1999), International Financial Statistics, Monthly Issues, Washington.

Januszewski, S., J. Köke and J. Winter (1999), Product Market Competition and Corporate Governance: An Empirical Investigation for Germany, ZEW Discussion Paper, forthcoming.

Karpoff, J. M. (1998), The Impact of Shareholder Activism on Target Companies: A Survey of Empirical Findings, Working Paper, University of Washington.

Nickell, S., D. Nicolitsas and N. Dryden (1997), What Makes Firms Perform Well?, European Economic Review 41, 783-796.

OECD (1997a), Economic Surveys: Hungary, OECD.

OECD (1997b), Economic Surveys: Russia, OECD.

OECD (1997c), Economic Surveys: Slovenia, OECD.

OECD (1998a), Economic Surveys: Czech Republic, OECD.

OECD (1999a), Economic Surveys: Poland, OECD.

OECD (1999b), Institutional Investors: Statistical Yearbook 1999, OECD.

Ost, F. (1984), Faktorenanalyse, in: Fahrmeir L. and A. Hamerle (ed.), Multivariate Statistische Verfahren, Berlin, ch. 12, 575-632.

Spearman, C. (1904), General Intelligence Objectively Determined and Measured, American Journal of Psychology 15, 201-293. 
Steiger, Max (2000), Institutionelle Investoren im Spannungsfeld zwischen Aktienmarktliquidität und Corporate Governance, Baden-Baden.

Tobin, J. (1958), Estimation of Relationships for Limited dependent Variables, Econometrica 26, 24-36.

World Bank (1997), Private Capital Flows to Developing Countries: The Road to Financial Integration, New York/NY.

Zellner, A. (1962), An Efficient Method of Estimating Seemingly Unrelated Regressions and Tests for Aggregation Bias, Journal of the American Statistical Association 57, 348368 . 